\title{
Divided by Death? Staging Mortality in the Early Modern Low Countries
}

\author{
Isabel Casteels, Louise Deschryver, and Violet Soen
}

Isabel Casteels studied history at the University of Amsterdam and is currently a research fellow of the Fwo (Research Foundation - Flanders). Her research interests combine the fields of cultural and anthropological history and the history of knowledge in the sixteenth-century Low Countries. She has published on religious rituals in merchant guilds in Tijdschrift voor Geschiedenis and on knowledge circulation in Enkhuizen in Tijdschrift Holland. A member of the KU Leuven research group of Early Modern History, she is now preparing her doctoral dissertation on the agency of audiences attending executions during the Dutch Revolt under the supervision of Violet Soen and Johan Verberckmoes.

Louise Deschryver studied history at KU Leuven and is a research fellow of the Fwo (Research Foundation - Flanders) at the research group Early Modern History of the same university. She researches the dynamics of sensory community formation and death rituals in the sixteenth-century Low Countries, on which she published an article in volume 4.1 of Early Modern Low Countries. The doctoral dissertation she is preparing under the supervision of Violet Soen and Johan Verberckmoes focuses on how the body and the senses created dynamics of confessional confrontation and/or co-existence in the religious and political upheavals of the Dutch Revolt.

Violet Soen is Associate Professor of Early Modern History at KU Leuven, and editor-in-chief of the series Habsburg Worlds at Brepols and Journal of Early Modern Christianity at De Gruyter. Her research focuses on the twin dynamics of religious war and peace in France, the Low Countries, the wider Habsburg World, and especially their borderlands. She is PI of the project Rest in Peace? Death during the Dutch Revolt (FwO, Research Foundation - Flanders) and co-PI of the EU Horizon 2020 Research \& Innovation programme RETOPEA, which studies religious peace and tolerance through history. She is the author of Vredehandel. Adellijke en Habsburgse verzoeningspogingen tijdens de Nederlandse Opstand (1564-1581) (Amsterdam 2012).

DOI 10.51750/emlc10005 - URL: http://www.emlc-journal.org

Publisher: Stichting EMLC

Copyright: The Author(s). This work is licensed under a Creative Commons Attribution-NonCommercial 4.0 International License. 


\begin{abstract}
This special issue examines the multifaceted phenomenon of death in the early modern Low Countries. When war, revolt, and disease ravaged the Netherlands, the experience of death came to be increasingly materialised in vanitas art, funeral sermons, ars moriendi prints, mourning poetry, deathbed psalms, memento mori pendants, grave monuments, épitaphiers, and commemoration masses. This collection of interdisciplinary essays brings historical, art historical, and literary perspectives to bear on the complex cultural and anthropological dimensions of death in past societies. It argues that the sensing and staging of mortality reconfigured confessional and political repertoires, alternately making and breaking communities in the delta of Rhine, Meuse, and Scheldt. As such, death's 'omnipresence' within the context of ongoing war and religious polarization contributed to the confessional and political reconfiguration of the early modern Low Countries.
\end{abstract}

Keywords: death, historical anthropology, religious war, Dutch Revolt 


\title{
Divided by Death? Staging Mortality in the Early Modern Low Countries
}

\author{
Isabel Casteels, Louise Deschryver, and Violet Soen
}

In the early morning of 4 October 1564, the Calvinist preacher Christoffel Fabritius was led to the pyre in the main square of Antwerp, the flourishing harbour city on the river Scheldt. ${ }^{1}$ The former Carmelite monk had been convicted by the urban authorities of infringing the anti-heresy edicts issued by the Habsburg overlords of the Low Countries. Although ritual burnings of Protestants deemed heretics such as these had become rather common over the preceding four decades, this time the audience that gathered did not stick to their compliant role. ${ }^{2}$ Spectators tried to free the preacher by throwing rocks taken from the ongoing construction works on the city hall. Possibly, the audience was incited by radical protestants, who had sung Calvinist-themed psalms at the prison's gate to comfort him the night before. As it turned out, the riots that had begun to free Fabritius merely prolonged his agony, as his body was already burning and heavily mutilated by the executioner before the latter fled the stage. Pamphlets and martyrologies soon provided details of the botched execution to titillate the 'mind's eye', registering not only his mutilated corpse with unusual detail (his body had shrunk to the size of a child's, with his bones visible, while the head had become unrecognisable) but also neatly capturing the sounds and smells experienced by the assembled crowd. Fabritius's execution illustrates how the staged rituals of death broke down at the eve of the Revolt, to be reconfigured throughout the separation of the Low Countries in the course of the Eighty Years' War. Were the Low Countries together 'until death did them part'?

Bringing together historical, literary, and art historical perspectives, the five contributions in this special issue examine death's 'omnipresence' within the context of the parish

1 Van der Lem, 'Christoffel Fabritius'; Génard, 'Personen te Antwerpen', 171, 198. This special issue is the result of the research project Rest in Peace? Death during the Dutch Revolt, funded by the Research Foundation Flanders (FWO, grant no. G059617N), in close collaboration with the EU Horizon 2020 Research \& Innovation programme RETOPEA, which studies religious peace and tolerance through history (grant no. 770309). The contents of this publication are the sole responsibility of co-PI Violet Soen and do not necessarily reflect the opinion of the European Union.

2 In a classic article, David Nicholls argued that the late medieval notion of ritual executions as purifying the community from subversive subjects broke down with the arrival of the Reformation, and executions furthered rather than halted its growth: Nicholls, 'The Theatre of Martyrdom'. 
church and the churchyard, in the central city square and its prison, and at home. In the first essay, Wendy Wauters addresses the late medieval olfactory panorama of death and disease in Antwerp's main urban parish of Our Lady, capturing both the sweet and stinking smells of mortality from a sample of devotional objects. Ruben Suykerbuyk follows up by scrutinising how the visual presence of the dead in church became increasingly contested throughout the Reformation - resulting in Protestants' physical destruction of tombs and Catholic attempts to re-materialise them in paper épitaphiers. Going out to the city square where heretics were brought to the stake, Isabel Casteels argues that Antwerp authorities sometimes preferred to hide this recurrent 'death spectacle' from the public eye by drowning Protestants 'in the dark', in the prison's basement. Coreligionists of the prosecuted, meanwhile, strove to publicize these drownings through song, protest, and print. Maureen Warren follows the course of publicized executions as she shifts the focus to domestic spheres in her contribution on the execution prints that well-to-do inhabitants of the Dutch Republic put on the walls in their homes. In the final essay, Kornee van der Haven leads us to the mourning scene, where the elegiac poems contemplating the corpse placed the staging of grief and sorrow within a literary context. Taken together, the contributions to this volume shed light on how the Low Countries came to be divided by death, as the daily encounter with mortality in the context of ongoing revolt, war, and religious strife contributed to their confessional and political reconfiguration.

\section{Death's Anthropology}

Unravelling death's repertoires - understood here as a set of available actions in a particular cultural context - reconnects with the crucial plea of Annales historians to contextualize death within the history of mentalities and practices, emotions and fears, bodies, and their gestures. ${ }^{3}$ These historians drew attention to death's anthropology, rather than solely charting a demographic north-western European death pattern with high mortality - in childbirth, infancy, or recurring epidemics. ${ }^{4}$ Since then, Reformation historians have argued for the far-reaching consequences of confessional divisions in theological conceptions of death and the afterlife, as well as in liturgy and burial practices in sixteenth century Europe. ${ }^{5}$ After the Council of Trent, Catholics insisted on the sacrament of

3 Hill, 'Making Lutherans', 18-19.

4 See Chaunu, La mort à Paris; Vovelle, La mort et l'Occident; Vovelle, Mourir autrefois; Delumeau, Le péché et la peur; Delumeau, La peur en Occident; Cressy, Birth, Marriage and Death; Naphy and Roberts (eds.), Fear in Early Modern Society. For the Low Countries specifically, see Devos and Janssens (eds.), 'Re-considering the Burden of Disease'; Curtis and Roosen (eds.), 'The Sex-Selective Impact of the Black Death'; Curtis, 'Was Plague an Exclusively Urban Phenomenon?'; Curtis and Han, 'The Female Mortality Advantage'; Van Bavel, Curtis, and Soens, 'Economic inequality'.

5 Karant-Nunn, The Reformation of Ritual; Koslofsky The Reformation of the Dead; Eire, From Madrid to Purgatory; Gordon and Marshall (eds.), The Place of the Dead; Laqueur, The Work of the Dead. For a general overview, see Tingle and Willis (eds.), Dying, Death, Burial and Commemoration in Reformation Europe. See for the impact on church and sacred space: Heal, 'Church Space and Religious Change'; Luria, 'Separated by Death?'; Coster, 'A microcosm of community'; Coster and Spicer (eds.), Sacred Space in Early Modern Europe. 
the Extreme Unction, elaborate funerals and commemorative masses led by a priest, and interment in sacred ground. Protestants, however, vehemently rejected this 'ritual industry of death', and came to defend a sober ars moriendi and a plain burial, in designated though not sacred churchyards. Rather than being equal before the only certainty in life, Catholics and Protestants became divided according to their views on predestination, the Last Judgement, and the afterlife, and segregated in their burial sites and practices. ${ }^{6}$ These anthropological readings prove crucial in understanding religious conflict on the ground. As Susan Karant-Nunn has demonstrated for example in her Reformation of Feeling, Catholic, Lutheran, and Calvinist clergy across the Holy Roman Empire tried to mould the deathbed feelings and mourning of their parishioners along confessional lines: Catholic priests continued to value crying after the passing of a loved one, even if they gradually rejected the medieval tradition of hiring 'wailing women'. Lutherans and Calvinists alike regarded outward crying as a lack of trust in or acceptance of God's judgement.?

Similarly, Natalie Zemon Davis's influential conceptualization of the 'rites of violence' has invited historians to consider how dead bodies and the stealing and discarding of corpses became a part of the religious violence between Catholics and Protestants in sixteenth-century France. ${ }^{8}$ In Davis's wake, historians of the Holy Roman Empire, France, and the British Isles have revealed the ritual repertoires behind confessional violence against the dead, turning it into a quintessential element of Europe's Wars of Religion. ${ }^{9}$ Recent contributions on the Dutch Revolt have also shown how growing confessional debates on a 'good death' and the afterlife turned death into one of the most fiercely debated rites of passage between the various confessional groups. ${ }^{10}$ In the Dutch Republic, the Reformed Church was installed as the sanctioned public religion, but not as its state church. As a result, inhabitants were confronted with the unique situation of a multi-confessional landscape of funerary practices, which had significant consequences for the development of distinctive Calvinist and (more clandestine) Catholic burying and mourning repertoires. ${ }^{11}$ Judith Pollmann has shown how the emotional attachment of Catholics to the church as the burial site of lost loved ones caused them to remain resentful of their loss of sacred

6 Gordon and Marshall, The Place of the Dead (eds.); Tingle and Willis (eds.), Dying, Death, Burial and Commemoration in Reformation Europe; Korpiola and Lahtinen (eds.), Planning for Death; Lahtinen and Korpiola (eds.), Dying Prepared.

7 Karant-Nunn, The Reformation of Feeling, 189-214.

8 Davis, 'The Rites of Violence', 64, 72, 82-83. See also the special issue in honour of Davis: Murdock, Roberts, and Spicer (eds.), 'Ritual and Violence'.

9 For the British Isles, see Tingle and Willis (eds.), Dying, Death, Burial and Commemoration in Reformation Europe; Walsham, The Reformation of the Landscape. For the Holy Roman Empire, see Koslofsky, The Reformation of the Dead; Koslofsky, 'Honour and Violence'; Heal, 'Church Space and Religious Change'; Luebke, 'Confessions of the Dead'. For France, see Roberts, 'Contesting Sacred Space'; Luria, 'Separated by Death?'; Luria, Sacred Boundaries.

10 Dombrecht, 'Edel, arm en rijk'; Bousard, 'Aan de rand van het graf; Deschryver, 'You Only Die Once'. For communal death rituals in the late medieval Low Countries, see Trio, 'Dood maar niet vergeten'; Trio, 'Obituaries or Anniversary Books'; Trio, 'Pro animabus nostris'; Trio, 'De instelling van jaargetijden'.

11 Mudde, Rouwen in de marge; Van den Broeke, 'No Funeral Sermons'; Van den Broeke, 'Baptism, Marriage and Funeral'; Lenarduzzi, Katholiek in de Republiek; Geraerts, Patrons of the Old Faith. 
space, while Calvinists found the presence of Catholic funeral processions in the public sphere hard to bear. ${ }^{12}$

Although the lion's share of historiographical attention has probably been paid to the radical shifts from the late medieval Christian repertoires of dying and death proposed by Reformers, recent scholarship has drawn attention to how medieval liturgical and sacramental life also proved resilient in cycles of life and death. Most importantly, in his The Work of the Dead, Tom Laqueur reminded us once again of the 'deep history' of man's dealing with mortal remains since the Greeks. ${ }^{13}$ Indeed, as Van der Haven discusses in his essay, in the post-Reformation Low Countries both Catholics and Calvinists still mediated their grief through biblical stances, urging them to make timely preparations for death; passages from both the Old and the New Testament figured as anchor points in dealing with death across the confessional divide. Andrew Spicer, moreover, has drawn attention to Calvinists' continued longing to be buried in traditional communal burial spaces and even churches, despite their renouncement of the theological concept of 'holy ground'. ${ }^{14}$

\section{Sensing Mortality}

Emphasizing that repertoires of dealing with death were embodied by the living, this volume puts the physical experience of death in the church, the city square, and at home centre stage. ${ }^{15}$ Wauters's analysis of the rubbed noses of sixteenth-century memento mori pendants reveals how early modern men and women dealt with the ever-threatening and growing presence of death in society with tactile and olfactory devotional practices. As Suykerbuyk shows in his essay, Catholics and Protestants increasingly engaged in entirely different sensory ways with the materiality of funereal culture in churches. Where Protestants physically destroyed tombs and funerary monuments during the iconoclasm of 1566, Catholics responded by also transferring memorials to another medium: from stone to paper. Moreover, as Casteels points out, the awareness that prisoners for religion could wield a sensory power with which they might seek to appropriate the rituals surrounding their execution, and thus the sympathy of the watching crowds, led the authorities in

12 Pollmann, 'Burying the dead, reliving the past'.

13 Laqueur, The Work of the Dead.

14 Spicer, 'Rest of Their Bones'.

15 Morgan, Religion and Material Culture, 1-3. Classic works on material and embodied Christianity in the Middle Ages remain Bynum and Freedman (eds.), Last Things; and Bynum, The Resurrection of the Body, in which she shows how the Reformation was an outburst of the hotly debated controversies on the status of holy matter within Christian teaching, which had been simmering from the thirteenth century onwards. Bynum's powerful assessment of matter's central role in Christian thinking has put 'the matter of belief as well as the body firmly back in the gaze of historians of early modern religion. For the Low Countries, see Roodenburg, 'Empathy in the Making'; Roodenburg (ed.), A Cultural History of the Senses in the Renaissance; Roodenburg, 'The Body in the Reformations'; Van Bruaene, Jonckheere, and Suykerbuyk (eds.), 'Beeldenstorm'; Suykerbuyk and Van Bruaene, 'Towering Piety'; Van Bruaene, 'Embodied Piety'; Van Bruaene, 'Exploring the Features and Challenges'; Jonckheere, Experiments in Decorum; Jonckheere, 'The Power of Iconic Memory'; Jonckheere, 'Michiel Coxcie'; Jonckheere, 'Images of Stone'. For more studies on material religion in the Low Countries, see also Suykerbuyk, The Matter of Piety; Suykerbuyk, 'Ter promotie der devotie'. 
Antwerp to drown prisoners in the dark city's dungeons rather than expose them to the light of public immolation. The execution prints discussed by Warren materialised the fleeting execution spectacle on the walls of well-to-do homes, their visualisation of gruesome death fleshing out examples of political and religious otherness to see and contemplate on a daily basis. Finally, as Van der Haven shows, reading and writing elegiac poems shaped feelings of loss in both Reformed and Catholic communities, and directed the senses both through inner contemplation or hearing these poems being read aloud. Hence, the senses were as important as theology and liturgy in death's confessional refashioning. ${ }^{16}$

Scholars of sensory studies argue that the use of the senses is a social construct, shifting over time, a practice that must be reconstructed within in each historical context. ${ }^{17}$ In early modern times, natural philosophical conceptions of sensory experience were framed by the Aristotelian heritage of the fivefold categorisation of the senses and the unilateral sensorial perception. In daily life, however, sensory experience was more often understood to be a dialectic dynamic between contexts and individuals than a straightforward process of information exchange. As Chris Woolgar has crucially argued, in late medieval times sensory experience was thought of as a physical two-way process between the perceiver and the perceived, in which not only sensory information but also qualities of sacredness or perniciousness might be exchanged. ${ }^{18}$ In this volume, Wauters scrutinises the smell of death in Antwerp's Church of Our Lady and illustrates how the putrid stench of decaying bodies was thought to contaminate all those who physically inhaled them. The seventeenth-century mourning poetry discussed by Van der Haven, on the other hand helps us to understand the subtle interaction between the bodily eye and the mind's eye in commemorating the sight of the corpse, transferring this visual image from the lyrical ' $\mathrm{I}$ ' to the poem's audiences.

The contributions to this volume stress that, from a sensory perspective, the experience of death changed significantly in this period, as the formation of new political and confessional identities affected the sensory impact of rituals surrounding death. Suykerbuyk reminds us that both Protestants and Catholics cared deeply about the 'sensescape' of death in church, but that they had very different ideas about their materialisation and sacralization. Even if liturgical death practices proved remarkably resilient throughout the Reformation, the multiple options that late medieval Christianity had offered slowly transformed into more demarcated choices. Building on the genre of the ars moriendi, which had originated in in the fifteenth century, a dying person could either incorporate all available protective rituals and objects - including burning candles and incense,

16 The growing interest in the senses in the Reformation was sparked by Matthew Milner's pioneering The Senses and the English Reformation. Recent examples of studies on the early modern senses include MacDonald, Murphy, and Swann (eds.), Sensing the Sacred in Medieval and Early Modern Culture; De Boer and Göttler (eds.), Religion and the Senses in Early Modern Europe; Roodenburg (ed.), A Cultural History of the Senses in the Renaissance; Milner, 'The Senses in Religion'; Baum, Reformation of the Senses.

17 Much of this scholarship is inspired by Alain Corbin's seminal work on bells and odours, as well as by the anthropological studies of François Laplantine and Constance Classen: Classen, The Deepest Sense; Classen, Howes, and Synnott, Aroma; Laplantine, Le social et le sensible. For an overview, see Howes, 'The Social Life of the Senses'.

18 Woolgar, 'What Makes Things Holy?'; Woolgar, The Senses in Late Medieval England. 
viewing, clasping, or kissing the crucifix, and being blessed with holy water - or opt for a sober deathbed ritual, in which Bible readings figured most prominently. With the Reformation, however, these sensory options became deliberate choices, in which lay men and women often reconstructed their take on devoutly sensing death with bits and pieces of older repertoires. Studying the omnipresence of death in early modern times from a sensorial perspective illuminates how people became increasingly aware of the significance of the sensory for their final moments and their eagerness to embody these in the best possible way. ${ }^{19}$

\section{Staging Death}

The growing importance of confessional choices led to a corresponding effort to ritually stage death and executions. Amidst the political and religious turmoil in the early modern Low Countries, how one died and how one remembered the dead became one of the most visible markers of the growing distance between confessional identities. The five essays in this volume all take account of this heightened awareness of ritual repertoires and show that these were no longer left to chance or individual interpretation, but instead became carefully staged performances. New norms were negotiated visually through death and violence, as executions, martyrdoms, and the smashing of images combined powerfully to formulate new divisions and allegiances between confessional and political groups.

By the sixteenth century, the Low Countries already had a history as a 'theatre state', as characterized by the elaborate visual culture and political rituals of the BurgundianHabsburg court, cities, citizens, and guilds. ${ }^{20}$ The display of death, such as in carefully staged funerals, processions, requiem masses, and public executions, was central to the visual culture of the ruling elite. ${ }^{21}$ With the outbreak of the Dutch Revolt, the staging of death became ever more important, as is exemplified by the exceptionally high numbers of commoners who were executed as martyrs for the Protestant faith on the eve of the religious wars, and the 'shocking' executions of leading aristocrats such as the Counts of Egmond and Hornes on the market square in Brussels. ${ }^{22}$ At the same time, the spectacular funeral processions of the stadtholders remained politically and confessionally ambiguous, as the state tried to accommodate a divided audience into the ritual. ${ }^{23}$ Ensuring that criminals suffered publicly was at the heart of the penal system in the Dutch Republic, and this encapsulated after-the-fact visualisations as well. ${ }^{24}$ The fact that the Low Countries had

19 Deschryver, 'You Only Die Once'.

20 Van Bruaene, 'The Habsburg Theatre State'; Brown, 'Ritual and State-Building'; Lecuppre-Desjardin, La ville des cérémonies; Bussels, Spectacle, rhetoric and power.

21 Arnade, Realms of Ritual; Thiry and Van Bruaene (eds.), 'Burgundian Afterlives'. On the early modern rituals of justice more generally, see Foucault, Surveiller et punir; Friedland, Seeing justice done; Terpstra, The Art of Executing Well.

22 Gregory, Salvation at Stake; Junot and Soen, 'User ou abuser'. See for a later period Parmentier, Juger en temps de troubles.

23 Janssen, 'Political ambiguity'.

24 Spierenburg, The Spectacle of Suffering; Van Duijnen, A Violent Imagination. 
quickly become the hub of the information technology that had reshaped the media landscape of early modern Europe played a crucial part. ${ }^{25}$ This allowed more people than ever before to fashion the rituals of death on paper, as the many martyr books, printed funeral sermons, and execution pamphlets and prints suggest. The Dutch Revolt appears in many ways as if it were a 'media war', in which the visualisation of violence and executions, such as the murders and rapes committed during the Spanish Furies, played a constitutive role in the forging of new identities. ${ }^{26}$ Therefore, the 'spectacle' of death can only be understood as a performative experience, considering the interplay between the staging of death and its spectators. ${ }^{27}$ As this volume suggests, the mediated representations of death rituals might even have become more important than the events themselves.

Strikingly, all of the essays reveal that the crowd, audience, or bystanders shaped the performance of death rituals. In entering the church, Wauters's late medieval urban parishioners chased both the worldly and spiritual stench of sinful corpses away, by praying for their salvation in requiem masses fragrant with incense. As both Suykerbuyk and Casteels show, seeing death memorialized in tombs or staged during executions made viewers - consciously or not - complicit in the event. Rather than simply refusing to continue to look at material artefacts staging death, the Protestant onlookers discussed by Suykerbuyk could take control by physically smashing images, or at least by damaging their appearance. Casteels argues that execution audiences appropriated the visual repertoires of capital punishment, spinning the memory of the execution ritual such that it is no longer recalled as a spectacle of justice. Even those executions carried out in secret were made visible by those who opposed them. Warren identifies the daily viewing of printed images of death and dismemberment in the domestic sphere as a signpost of political and confessional loyalties. Finally, the elegiac poems studied by Van der Haven dwell on 'the bystanders, defeated and horrified in the soul, /[who] Try to calm their mourning by complaining', playing ingeniously on the outward and inward lamentation of souls, fashioning the performance of grief and the loss of their intended audiences.

\section{Divided by Death?}

The power of death to make or break communities came into sharp focus in the early modern Low Countries, which accommodated part of Europe's new confessional frontiers. ${ }^{28}$ Although age-old traditions, liturgies, and sacraments were not easily erased, and early modern people often managed to live together in a world divided by faith,

25 Pettegree and Van der Weduwen, The Bookshop of the World.

26 Voges, Das Auge der Geschichte; Stensland, Habsburg Communication in the Dutch Revolt; Pipkin, Rape in the Republic; Deen, Amsterdam 'Moorddam'.

27 Merback, The Thief, the Cross and the Wheel; Edgerton, Pictures and punishment; Santing, Baert, and Traninger, (eds.), Disembodied Heads; Vanhauwaert, 'Van sint Jans onthoofdinghe'; Macsotay, Van der Haven and Vanhaesebrouck (eds.), The Hurt(ful) Body; Vanhaesebrouck, 'Lichamelijkheid en emoties'; Van der Stighelen and Roelens, 'Made in Heaven'.

28 De Ridder and Soen, 'Transregional history'; Soen, 'Which religious history'. 
the sensory repertoires of staging death became important rallying points for the various confessional and politically opposing groups in society. ${ }^{29}$ During the Dutch Revolt, the iconoclasm in churchyards and churches caused ruptures and visual wounds to appear in sacred spaces. ${ }^{30}$ The damaged face of the statue of Isabella van Bourbon on her funeral monument, which was erected in Antwerp's St. Michael's abbey, remains a visual reminder of what was at stake. Choosing between an austere and spiritual or a more lavish funeral, to (overtly) cry or not to cry while mourning a lost one, or even how willingly one mounted the scaffold to be publicly burned - these were all confessional markers. Moreover, how to die and experience death came to signify something more than religious views alone, as the fashioning of death became closely intertwined with political and ideological views. New and gradually diverging ways of seeing and sensing death were now being transmitted from generation to generation, and they carried with them implications of confessional allegiance, which had no accounted precedents in the fifteenth century. Choosing how to die would itself become a decision that could make a difference between life and death for surviving family members in the Habsburg Netherlands, where 'heretical' deaths continued to be punished and investigated. In the Dutch Republic, the distinction between Catholic and Reformed families in being able to have public funeral ceremonies had far-reaching consequences, although Catholics found ways to strengthen their community with funeral rituals partly held out of the public eye, in the privacy of their clandestine house churches. ${ }^{31}$

At the same time, as the contributions in this issue show, these diverging repertoires were highly unstable and could be changed, inverted, and moulded according to context and intentions. Confessional tensions were exacerbated by divisions over the staging of death, which added to the dynamics of revolt, civil war, and the eventual disintegration of the Low Countries. The two new states that emerged strongly linked their identities to how they dealt with death. In the Habsburg Netherlands, the celebration of the 'very special dead' - the martyrs and the saints - became the focal point of the Catholic Reformation around which the governors Isabella and Albrecht built their legitimacy. ${ }^{32}$ In the Dutch Republic, on the other hand, Catholic death rituals no longer had a place in the public realm, but biblical and medieval martyrological traditions were incorporated into the ways in which 'political martyrs' like Oldenbarnevelt and the brothers De Witt were revered, such as their belongings and body parts being stored as relics. ${ }^{33}$

The 1564 execution of Fabritius, a visual and performative spectacle intended to purify the Antwerp community from sin and evil, caused ruptures instead. As such, this execution laid bare how various groups experienced death through very different visual and sensorial repertoires. At the same time, his death functioned as a symbol, enabling Protestants to make a stand against the authorities by collective action during his execution and thereafter by publicizing his death in print and song. The afterlife of Fabritius's execution is

29 Kaplan, Divided by Faith.

30 Bousard, 'Aan de rand van het graf; Soen and Van Bruaene, 'Sacrale ruimtes'.

31 Mudde, Rouwen in de marge; Lenarduzzi, Katholiek in de Republiek.

32 Duerloo and Thomas (eds.), Albrecht \& Isabella.

33 Janssen, 'Het stokje van Oldenbarneveldt'. 
a telling example of this dynamic. The authorities' opponents appropriated the spectacle of death, turning the visual representation of his death into a textual one, which might have allowed them to better communicate the sensuous suffering of the martyred monk. Immediately after the execution, descriptions of his painful death appeared in print, leading to his inclusion in well-known Calvinist martyrologies. These pamphlets also contained a song, which was ultimately absorbed into the Geuzenliedboek, the collection of the most important rebel songs of the Dutch Revolt.

Taken together, then, the essays in this special issue demonstrate that the encounter with mortality was a constituent part of everyday life in the early modern Low Countries, and foremost show that this experience became embedded in scripted and ritual repertoires, sometimes making and sometimes breaking communities. The shared certainty of death left a mark on the culture of the early modern Low Countries. Especially in the sixteenth and seventeenth centuries, when war and disease ravaged the region, it resulted in the production of vanitas art, funeral sermons, ars moriendi prints, mourning poetry, deathbed psalms, hymns, memento mori pendants, grave monuments, épitaphiers, and commemoration masses. Hence, this issue helps to convey how interdisciplinary dialogue and the inclusion of a wide range of sources is crucial in trying to understand the complex anthropological structures of experiences in the past.

Demonstrating how these rituals and repertoires were at stake in not only religious, but also political and cultural debates in the early modern Low Countries may help us to better understand how modern-day cultural repertoires of staging, sensing, and experiencing death can divide or unite communities. While editing this issue, the death of George Floyd exposed the deep divisions and tensions at work within both American society and across much of the globe, and ignited a whole range of these sensory or visual repertoires: from chanting and rock-throwing protesters, to silently kneeling policemen, and a livestream of Floyd's memorial service, showing the gold coffin in which he is buried. At the same time, the world is now dealing with the CoviD-19 pandemic that caused national communities to turn inwards and close their borders. Within these communities, however, new solidarities emerge, for example through the collective agony over the lack of proper burials for beloved ones, or through the organized applauding for caregivers. Although the situation today of course is very different from the early modern period, it is interesting to see how the repertoires through which mortality is sensed and staged are fundamental for the formation of communities and can function as rallying points for change, just as they did in the early modern Low Countries.

\section{Bibliography}

Arnade, Peter, Realms of Ritual. Burgundian Ceremony and Civic Life in Late Medieval Ghent (Ithaca 1996).

Baum, Jacob, Reformation of the Senses. The Paradox of Religious Belief and Practice in Germany (Urbana 2019).

Bavel, Bas van, Daniel Curtis, and Tim Soens, 'Economic inequality and institutional adaptation in response to flood hazards. A historical analysis', Ecology and Society 23 (2018/4) art. 30.

Boer, Wietse de, and Christine Göttler (eds.), Religion and the Senses in Early Modern Europe (Leiden 2013). 
Bousard, Tiffany, 'Aan de rand van het graf. De transformatie van het funeraire leven en landschap in Antwerpen en Brugge tijdens de calvinistische republieken (1577/1578-1584/1585)', in Liesbeth Geevers and Violet Soen (eds.), Sacrale ruimte in de vroegmoderne Nederlanden (Leuven 2017) 59-86.

Broeke, Leon van den, 'Baptism, Marriage and Funeral. Reformed Exclusivity or Religious Intolerance?', in Herman Selderhuis and Jan Marius Jacob Lange van Ravenswaay (eds.), Reformed Majorities in Early Modern Europe (Göttingen 2015) 213-225.

Broeke, Leon van den, 'No Funeral Sermons. Dutch or Calvinistic Prohibition?', in Tarald Rasmussen and Jon Oygarden Flaeten (eds.), Preparing for Death, Remembering the Dead (Göttingen 2015) 361-377.

Brown, Andrew, 'Ritual and State-Building. Ceremonies in Late Medieval Bruges', in Jacoba van Leeuwen (ed.), Symbolic communication in late medieval towns (Leuven 2006) 1-28.

Bussels, Stijn, Spectacle, Rhetoric and Power. The Triumphal Entry of Prince Philip of Spain into Antwerp (Amsterdam 2012).

Bynum, Caroline, and Paul Freedman (eds.), Last Things. Death and the Apocalypse in the Middle Ages (Philadelphia 1999).

Bynum, Caroline, Christian Materiality. An Essay on Religion in Late Medieval Europe (New York 2011).

Bynum, Caroline, The Resurrection of the Body in Western Christianity, 200-1336 (New York 1995).

Chaunu, Pierre, La mort à Paris. XVIe, XVIIe et XVIIIe siècles (Paris 1978).

Classen, Constance, David Howes, and Anthony Synnott, Aroma. The Cultural History of Smell (London 1994).

Classen, Constance, The Deepest Sense. A Cultural History of Touch (Urbana 2012).

Cohen, Esther, The Crossroads of Justice Law and Culture in Late Medieval France (Leiden 1993).

Coster, William, 'A microcosm of community. Burial, space and society in Chester, 1598-1633', in William Coster and Andrew Spicer (eds.), Sacred space in early modern Europe (Cambridge 2005) 124-143.

Coster, William, and Andrew Spicer (eds.), Sacred Space in Early Modern Europe (Cambridge 2005).

Cressy, David, Birth, Marriage and Death. Ritual, Religion and the Life-Cycle in Tudor and Stuart England (Oxford 1997).

Curtis, Daniel, and Joris Roosen, 'The Sex-Selective Impact of the Black Death and Recurring Plagues in the Southern Netherlands, 1349-1450', American Journal of Physical Anthropology 164 (2017/2) 246-259.

Curtis, Daniel, 'Was Plague an Exclusively Urban Phenomenon? Plague Mortality between City and Countryside in the Seventeenth-Century Low Countries', Journal of Interdisciplinary History 47 (2016/2) 139-170.

Curtis, Daniel, and Qijun Han, 'The Female Mortality Advantage in the Seventeenth-Century Rural Low Countries', Gender \& History 33 (2021/1) 50-74.

Davis, Natalie Zemon, 'The Rites of Violence. Religious Riot in Sixteenth-Century France', Past \& Present 59 (1973) 51-91.

Deen, Femke, Amsterdam 'Moorddam'. Publiek debat en propaganda in Amsterdam tijdens de Nederlandse Opstand, 1566-1578 (Amsterdam 2015).

Delumeau, Jean, La peur en Occident (XIV-XVII Siècles). Une cité assiégée (Paris 1978).

Delumeau, Jean, Le péché et la peur. La culpabilisation en Occident, XIIIe-XVIIIe siècles (Paris 1983).

De Ridder, Bram, and Violet Soen, 'Transregional History. New Perspectives on Early Modern Borders and Borderlands in the Low Countries and the Habsburg Worlds', in Bram De Ridder, Violet Soen, Werner Thomas, and Sophie Verreyken (eds.), Transregional Territories. Crossing Borders in the Early Modern Low Countries and Beyond (Turnhout 2020) 13-19.

Deschryver, Louise, 'You Only Die Once. Calvinist Dying and the Senses in Lille and Tournai During the Dutch Revolt', Early Modern Low Countries 4 (2020/1) 35-57.

Devos, Isabelle, and Angélique Janssens (eds.), 'Re-Considering the Burden of Disease in the Low Countries in Past Centuries', special issue of Tijdschrift voor Sociale and Economische Geschiedenis 14 (2017/4).

Dombrecht, Kristof, 'Edel, arm en rijk, maakt de dood gelijk? Sociale ongelijkheid (post mortem) in plattelandsgemeenschappen ten noorden van Brugge (1500-1579), Revue belge de Philologie et d'Histoire 91 $(2013 / 2) 257-287$. 
Duerloo, Luc, and Werner Thomas (eds.), Albrecht \& Isabella 1598-1621 (Turnhout 1998).

Duijnen, Michel van, A Violent Imagination. Printed Images of Violence in the Dutch Republic, 1650-1700. PhD diss., Vrije Universiteit Amsterdam, 2019.

Edgerton, Samuel, Pictures and Punishment. Art and Criminal Prosecution During the Florentine Renaissance (Ithaca 1985).

Eire, Carlos, From Madrid to Purgatory. The Art and Craft of Dying in Sixteenth-Century Spain (Cambridge 1995).

Foucault, Michel, Surveiller et punir. Naissance de la prison (Paris 1975).

Friedland, Paul, Seeing Justice Done. The Age of Spectacular Capital Punishment in France (Oxford 2012).

Génard, Pierre, 'Personen te Antwerpen in de XVIe eeuw voor het feit van religie gerechtelijk vervolgd', Antwerpsch Archievenblad/Bulletin des Archives d'Anvers 9 (1872) 1-471.

Geraerts, Jaap, Patrons of the Old Faith. The Catholic Nobility in Utrecht and Guelders, c.1580-1702 (Leiden 2019).

Gregory, Brad, Salvation at Stake. Christian Martyrdom in Early Modern Europe (Cambridge, MA 1999).

Gordon, Bruce, and Peter Marshall (eds.), The Place of the Dead. Death and Remembrance in Late Medieval and Early Modern Europe (Cambridge 2000).

Heal, Bridget, 'Church Space and Religious Change in Reformation Germany', in Miri Rubin and Ira Katznelson (eds.), Religious Conversion. History, Experience and Meaning (Farnham, 2014) 99-122.

Hill, Kat, 'Making Lutherans', Past \& Present Supplement 12 (2017) 9-32.

Howes, David, 'The Social Life of the Senses', Ars Vivendi Journal 3 (2013) 4-23.

Janssen, Geert, 'Het stokje van Oldenbarneveldt', Dutch Revolt, https://dutchrevolt.leiden.edu/dutch/symbolen/Pages/stokje.aspx (Accessed on 19 November 2020).

Janssen, Geert, 'Political ambiguity and confessional diversity in the funeral processions of stadholders in the Dutch Republic', The Sixteenth Century Journal 40 (2009) 283-301.

Jonckheere, Koenraad, 'Images of Stone. The Physicality of Art and the Image Debates in the Sixteenth Century', Netherlands Yearbook for History of Art 62 (2013) 116-147.

Jonckheere, Koenraad, 'Michiel Coxcie. First Painter of the Counter-Reformation', in Koenraad Jonckheere (ed.), Michiel Coxcie and the Giants of His Age (London 2013) 116-137.

Jonckheere, Koenraad, 'The Power of Iconic Memory. Iconoclasm as a Mental Marker', Low Countries Historical Review 131 (2016/1) 141-154.

Jonckheere, Koenraad, Experiments in Decorum. Antwerp Art After Iconoclasm (1566-1585) (London 2013).

Junot, Yves, and Violet Soen, 'User ou abuser des confiscations. Les voies tortueuses de la punition, du pardon et de la récompense par les Habsbourg d'Espagne durant la Révolte (Pays-Bas espagnols, 15661609)', in Yves Junot and Violet Soen (eds.), Confisquer, restituer, redistribuer. Punition et réconciliation matérielles dans les territoires des Habsbourg et en France (XVIe et XVIIe siècles) (Valenciennes 2020) 87-132.

Kaplan, Benjamin, Divided by Faith. Religious Conflict and the Practice of Toleration in Early Modern Europe (Cambridge, MA 2007).

Karant-Nunn, Susan, The Reformation of Feeling (Oxford 2010).

Karant-Nunn, Susan, The Reformation of Ritual. An Interpretation of Early Modern Germany (Abingdon 2007).

Korpiola, Mia, and Anu Lahtinen (eds.), Planning for Death. Wills and Death-Related Property Arrangements in Europe, 1200-1600 (Leiden 2018).

Koslofsky, Craig, 'Honour and Violence in German Lutheran Funerals in the Confessional Age', Social History $20(1995 / 3)$ 315-337.

Koslofsky, Craig, The Reformation of the Dead. Death and Ritual in Early Modern Germany, 1450-170o (New York 2000).

Lahtinen, Anu, and Mia Korpiola (eds.), Dying Prepared in Medieval and Early Modern Northern Europe (Leiden 2018).

Laplantine, François, Le social et le sensible (Paris 2005). 
Laqueur, Tom, 'Crowds, Carnival, and the State in English Executions, 1604-1868', in, A. Lee Beier, David Cannadine, and James M. Rosenheim (eds.), The First Modern Society. Essays in English History in Honour of Lawrence Stone (Cambridge 1989) 305-356.

Laqueur, Tom, The Work of the Dead. A Cultural History of Mortal Remains (Princeton 2015).

Lecuppre-Desjardin, Elodie, La ville des cérémonies. Essai sur la communication politique dans les anciens Pays-Bas bourguignons (Turnout 2004).

Lem, Anton van der, 'Fabritius, Christoffel', Dutch Revolt, https://dutchrevolt.leiden.edu/dutch/personen/F/ Pages/fabritius.aspx (Accessed on 9 June 2020).

Lenarduzzi, Carolina, Katholiek in de Republiek. De belevingswereld van een religieuze minderheid $1570-$ 1750 (Nijmegen 2020).

Luebke, David, 'Confessions of the Dead. Interpreting Burial Practice in the Late Reformation', Archiv Für Reformationsgeschichte 101 (2010/1) 55-79.

Luria, Keith, Sacred Boundaries. Religious Coexistence and Conflict in Early Modern France (Washington 2005).

Luria, Keith, 'Separated by Death? Burials, Cemeteries and Confessional Boundaries in SeventeenthCentury France', French Historical Studies 24 (2001/2) 185-222.

MacDonald, Robin, Emilie Murphy, and Elizabeth Swann (eds.), Sensing the Sacred in Medieval and Early Modern Culture (Abingdon 2018).

Macsotay, Tomas, Cornelis van der Haven, and Karel Vanhaesebrouck (eds.), The Hurt(ful) Body. Performing and beholding pain, 1600-180o (Manchester 2017).

Merback, Mitchell, The Thief, the Cross and the Wheel. Pain and the Spectacle of Suffering in Medieval and Renaissance Europe (Chicago 1998).

Milner, Matthew, 'The Senses in Religion. Towards the Reformation of the Senses', in Herman Roodenburg (ed.), A Cultural History of the Senses in the Renaissance (London 2014) 87-105.

Milner, Matthew, The Senses and the English Reformation (Farnham 2011).

Morgan, David (ed.), Religion and Material Culture. The Matter of Belief (London 2010).

Mudde, Caroline, Rouwen in de marge. De materiële rouwcultuur van de katholieke geloofsgemeenschap in vroegmodern Nederland. PhD diss., Utrecht University, 2018.

Murdock, Graeme, Penny Roberts, and Andrew Spicer (eds.), 'Ritual and Violence. Natalie Zemon Davis and Early Modern France', Past \& Present Supplement 7 (2012).

Naphy, William, and Penny Roberts (eds.), Fear in Early Modern Society (Manchester 1997).

Nicholls, David, 'The Theatre of Martyrdom in the French Reformation', Past \& Present 121 (1988) 49-73.

Parmentier, Romain, Juger en temps de troubles. Justice pénale et criminalité à Namur au temps des 'Malheurs' (1650-1700) (Louvain-la-Neuve 2015).

Pettegree, Andrew, and Arthur van der Weduwen, The Bookshop of the World. Making and Trading Books in the Dutch Golden Age (New Haven 2019).

Pipkin, Amanda, Rape in the Republic. Formulating Dutch Identity, 1609-1725 (Leiden 2013).

Pollmann, Judith, 'Burying the dead, reliving the past. Ritual, resentment and sacred space in the Dutch Republic', in Benjamin Kaplan, Henk van Nierop, Judith Pollmann, and Bob Moore (eds.), Catholic communities in Protestant states. Britain and the Netherlands, c. 1570-1720 (Manchester 2009) 84-102.

Roberts, Penny, 'Contesting Sacred Space. Burial Disputes in Sixteenth-Century France', in Bruce Gordon and Peter Marshall (eds.), The Place of the Dead. Death and Remembrance in Late Medieval and Early Modern Europe (New York 2000) 131-148.

Roodenburg, Herman (ed.), A Cultural History of the Senses in the Renaissance (London 2014).

Roodenburg, Herman, 'Empathy in the Making. Crafting the Believer's Emotions in the Late Medieval Low Countries', Low Countries Historical Review 129 (2014/2) 42-62.

Roodenburg, Herman, 'The Body in the Reformations', in Ulinka Rublack (ed.), The Oxford Handbook of the Protestant Reformations (New York 2017) 643-666.

Roosen, Joris, and Daniel Curtis, 'The Light Touch of the Black Death in the Southern Netherlands. An Urban Trick?', The Economic History Review 72 (2019/1) 32-56. 
Santing, Catrien, Barbara Baert, and Anita Traninger (eds.), Disembodied Heads in Medieval and Early Modern Culture (Leiden 2013).

Soen, Violet, 'Which religious history for the (two) early modern Netherlands before 1648? Questions, trends and perspectives', Revue d'histoire ecclésiastique 112 (2017/3-4) 758-788.

Soen, Violet, and Anne-Laure Van Bruaene, 'Sacrale ruimtes in de vroegmoderne Nederlanden. Perspectieven en dwarsverbanden', in Liesbeth Geevers and Violet Soen (eds.), Sacrale ruimte in de vroegmoderne Nederlanden (Leuven 2017) 7-28.

Spicer, Andrew, 'Rest of Their Bones. Fear of Death and Reformed Burial Practices', in William Naphy and Penny Roberts (eds.), Fear in Early Modern Society (Manchester 1997) 167-183.

Spierenburg, Pieter, The Spectacle of Suffering (Cambridge 1984).

Stensland, Monica, Habsburg Communication in the Dutch Revolt (Amsterdam 2012).

Suykerbuyk, Ruben, 'Ter promotie der devotie. Materiële voorzieningen en offervaardigheid voor de Sint-Leonarduscultus in Zoutleeuw (1453-1505)', in Liesbeth Geevers and Violet Soen (eds.) Sacrale ruimte in de vroegmoderne Nederlanden (Leuven 2017) 29-57.

Suykerbuyk, Ruben, and Anne-Laure Van Bruaene, 'Towering Piety. Sacrament Houses, Local Patronage and an Early Counter-reformation Spirit in the Low Countries (1520-1566)', Netherlands Yearbook for History of Art 67 (2017) 118-159.

Suykerbuyk, Ruben, The Matter of Piety. Zoutleeuw's Church of Saint Leonard and Religious Material Culture in the Low Countries (c. 1450-1620) (Leiden 2020).

Terpstra, Nicholas, The Art of Executing Well. Rituals of Execution in Renaissance Italy (Kirksville 2008).

Thiry, Steven, and Anne-Laure Van Bruaene (eds.) 'Burgundian Afterlives. Appropriating the Dynastic Past(s) in the Habsburg Netherlands', special issue of Dutch Crossing 43 (2019/1).

Tingle, Elizabeth, and Jonathan Willis (eds.), Dying, Death, Burial and Commemoration in Reformation Europe (Abingdon 2016).

Trio, Paul, 'Obituaries or Anniversary Books. Handle with Care! The Example of the Ypres Confraternity of Our Lady', in Rolf de Weijert (ed.), In Living Memoria. Studies in Medieval and Early Modern Memorial Culture in Honour of Truus van Bueren (Hilversum 2011) 179-193.

Trio, Paul, 'De instelling van jaargetijden (anniversaria) in de Lage Landen tijdens de Middeleeuwen. Een eerste balans', Signum 13 (2001/1) 31-37.

Trio, Paul, 'Dood maar niet vergeten. De gerestaureerde memorielijst van de Brugse schilders', Signum 14 (2002/1) 8-11.

Trio, Paul, 'Pro animabus nostris et antecessorum nostrorum in elemosinam. Memorieviering in de Middeleeuwse Norbertijnenabdij te Drongen (tot ca. 1580)', in Herman Janssens (ed.), Memorievieringen bij Norbertijnen (Averbode 2006) 49-52.

Van Bruaene, Anne-Laure, 'Embodied Piety. Sacrament Houses and Iconoclasm in the Sixteenth-century Low Countries', Low Countries Historical Review 131 (2016/1) 36-58.

Van Bruaene, Anne-Laure, Koenraad Jonckheere, and Ruben Suykerbuyk (eds.), 'Beeldenstorm. Iconoclasm in the Low Countries', special issue of Low Countries Historical Review 131 (2016/1).

Van Bruaene, Anne-Laure, 'The Habsburg Theatre State. Court, City and the Performance of Identity in the Early Modern Southern Low Countries', in Robert Stein and Judith Pollmann (eds.), Networks, Regions and Nations. Shaping Identities in the Low Countries, 1300-1650 (Leiden 2009) 131-150.

Van Bruaene, Anne-Laure, 'Exploring the Features and Challenges of the Urban Parish Church in the Southern Low Countries. The Case of Sixteenth-Century Ghent', in Andrew Spicer (ed.), Parish Churches in the Early Modern World (Farnham 2016) 53-76.

Van der Stighelen, Katlijne, and Jonas Roelens, 'Made in Heaven, Burned in Hell. The Trial of the Sodomite Sculptor Hiëronymus Duquesnoy (1602-1654)', in Hannelore Magnus and Katlijne Van der Stighelen (eds.), Facts \& Feelings. Retracing Emotions of Artists (Turnhout 2015) 101-138.

Van Engen, John, 'Multiple Options. The World of the Fifteenth-Century Church', Church History 77 (2/2008) 257-284.

Vanhaesebrouck, Karel, 'Lichamelijkheid en emoties op het vroegmoderne podium. De martelaar als theatraal effect', Tijdschrift voor Geschiedenis 126 (2013) 516-529. 
Vanhauwaert, Soetkin, 'Van sint Jans onthoofdinghe. The Sculpted Saint John's Head in Performances of Saint John's Beheading in the Low Countries', in Barbara Baert and Sophia Rochmes (eds.), Decapitation and Sacrifice. Saint John's Head in Interdisciplinary Perspectives. Text, Object, Medium (Leuven 2017) 93-138.

Voges, Ramon, Das Auge der Geschichte. Der Aufstand der Niederlande und die Französischen Religionskriege im Spiegel der Bildberichte Franz Hogenbergs (ca. 1560-1610) (Leiden 2019).

Vovelle, Michel, La mort et l'Occident de 1300 à nos jours (Paris 1983).

Vovelle, Michel, Mourir autrefois. Attitudes collectives devant la mort aux XVIIe et XVIIIe siècles (Paris 1974)

Walsham, Alexandra, The Reformation of the Landscape. Religion, Identity, and Memory in Early Modern Britain and Ireland (Oxford 2012).

Woolgar, Chris, 'What Makes Things Holy? The Senses and Material Culture in the Later Middle Ages', in Robin MacDonald, Emilie Murphy, and Elizabeth Swann (eds.), Sensing the Sacred in Medieval and Early Modern Culture (Abingdon 2018) 60-78.

Woolgar, Chris, The Senses in Late Medieval England (New Haven 2006). 